Katarzyna Sonnenberg*

\title{
W poszukiwaniu sposobu opisu natury ludzkiej. Strategie ironii we wczesnych utworach Akutagawy Ryūnosuke
}

DOI: http://dx.doi.org/10.12775/LC.2017.059

Streszczenie: Artykul jest poświęcony przejawom ironii w trzech opowiadaniach Akutagawy Ryūnosuke: Hana (Nos), Imogayu (Kleik z batatów) i Hankachi (Chusteczka), które ukazały się w 1916 roku i pozwolity autorowi zaistnieć w świecie literatów. Skupienie się na stosowanych przez pisarza strategiach ironii w utworach, w których z różnych perspektyw ukazywany jest ludzki egoizm i łatwość powierzchownej oceny innych, a które inspirowane są zarówno literaturą klasyczną, jak i współczesnością, pozwala dostrzec tematy i techniki powracające także w późniejszych dziełach Akutagawy o charakterze autobiograficznym.

Słowa kluczowe: Akutagawa Ryūnosuke, ironia, Hana, Imogayu, Hankachi

Adiunkt w Zakładzie Japonistyki i Sinologii Uniwersytetu Jagiellońskiego, autorka monografii i artykułów poświęconych rozwojowi powieści w okresach Edo i Meiji. E-mail: katarzyna.sonnenberg@uj.edu.pl. 


\title{
How to describe human nature? Strategies of irony in Akutagawa Ryūnosuke's early short-stories
}

\begin{abstract}
The article focuses on the manifestations of irony in Akutagawa Ryūnosuke's three early short-stories: Hana (Nose), Imogayu (Yam Gruel) and Hankachi (Handkerchief), which all appeared in 1916, assuring their author a solid place among the literati of the time. In the narratives Akutagawa - inspired by both classical literature and contemporary social phenomena - approaches from different perspectives the problem of human egoism and overwhelming tendency to pass superficial judgments on others. The analysis of the strategies of irony employed by Akutagawa leads to highlighting the themes and techniques recurrent also in his later autobiographical writings.
\end{abstract}

Keywords: Akutagawa Ryūnosuke, irony, Hana, Imogayu, Hankachi

\section{Wprowadzenie}

kutagawa Ryūnosuke (1892-1927) jest uznawany za „pisarza żądnego przygód” (bōkenteki na sakka $)^{1}$ i tytuł ten nie pozostaje bez związku z wyraźnymi w jego twórczości poszukiwaniami odpowiedniej dla przekazywanych treści formy wyrazu, jak również z zastosowaniem wielogłosowości w narracji. Yabu no naka ( $W$ gaszczu, 1922), jedno z jego najsłynniejszych opowiadań, w którym została podważona wiarygodność każdego z narratorów, jest wyrazem jego zainteresowania „formalnymi możliwościami tkwiącymi w tworzeniu mnogich perspektyw, rodzących efekt ironiczny"2. Owo zainteresowanie Akutagawy znaczeniem i kształtem powieści znalazło także odbicie w dyskusji, którą prowadził z Tanizakim Jun'ichirō tuż przed swą samobójczą śmiercią w 1927 roku³.

Zjawisko wielogłosowości w narracji znane było Akutagawie z literatury klasycznej, do której nierzadko odwoływał się w swojej twórczości. Jednak ów sugerowany zaledwie w tekstach klasycznych rozdźwięk pomiędzy słowami i świadomością bohaterów, a także między spojrzeniem narratora i możliwą reakcją czytelnika, został w opowiadaniach Akutagawy wysunięty na pierwszy plan. Jego stałe zaproszenie do krytycznego spojrzenia na to, co przedstawiane, oraz na możliwości poznawcze człowieka zdawało się odzwierciedlać to, jak podchodził do samego siebie, owo stałe poddawanie krytyce „artysty w sobie samym”.

1 H. Hashiura, Yokomitsu Riichi - kankaku to shukumei, „Kokubungaku: kaishaku to kyōzai no kenkyū” 2001, t. 46 , nr 11, s. 36.

2 D. C. Washburn, The Dilemma of the Modern in Japanese Fiction, New Haven-London 1995, s. 226.

3 R. Akutagawa, Bungeitekina, amari bungeitekina, [w:] Gendai nihon bungaku taikei, t. 43: Akutagawa Ryūnosuke shū, Tōkyō 1977, s. 322-353.

4 M. Ueda, Modern Japanese Writers, Stanford 1976, s. 111. 
Celem prezentowanej publikacji jest analiza sposobu tworzenia ironii w trzech opublikowanych w 1916 roku utworach Akutagawy: Hana (Nos), Imogayu (Kleik z batatów) i Hankachi (Chusteczka) $)^{5}$ Utwory te można przeciwstawiać późniejszym opowiadaniom, zwłaszcza tym wydanym tuż przed śmiercią pisarza, jak Haguruma (Koło zębate, 1927) czy Aru ahō no isshō (Życie szaleńca, 1927), w których Akutagawa z gorzką ironią spogląda na naturę ludzką przez pryzmat własnego życia. Skupienie się na mechanizmach ironii w pierwszych utworach autora może służyć wskazaniu pewnej spójności całego jego dzieła, w centrum którego od początku znajdowało się ukazywanie ograniczoności ludzkiej percepcji i egoizmu ludzkiej natury.

\section{Charakterystyka wczesnych opowiadań Akutagawy}

Zdaniem Horiego Tatsuo twórczość Akutagawy można podzielić na dwa okresy: pierwszy rozpoczyna ukazanie się opowiadania Hana (Nos, 1916), a kończy wydanie Rokunomiya no himegimi (Księżniczka Rokunomiya, 1922), utworu, który ma najpełniej realizować artystyczne postulaty debiutującego autora ${ }^{6}$. Powieść Kappa (Kappy, 1927), a także wspomniane już wcześniej Haguruma czy Aru ahō no isshō zaliczane są do drugiego okresu. Jednymi z kryteriów takiego podziału są nawiązania do literatury klasycznej i osadzenie narracji w odległym czasie - zabiegi obecne zwłaszcza w utworach z pierwszego okresu. Yamanouchi podkreśla, że w latach od 1915 do 1922 Akutagawa intensywnie nawiązywał do dawnych opowieści, zwłaszcza tych z okresu Heian ${ }^{7}$. Znanym przykładem jest Rashōmon (Rashōmon, 1915), opowiadanie, które czerpie z Konjaku monogatari (Księga XXIX, nr 18 oraz Księga XXXI, nr 1) oraz z Hojōki (Zapiski z pustelni, XIII wiek).

Wykorzystywanie bardziej lub mniej znanych tekstów literatury japońskiej i obcej było nierzadko powodem, dla którego zarzucano Akutagawie brak oryginalności ${ }^{8}$. Porównywano go do artysty, który układa mozaikę, „łącząc ze sobą w nowe dzieła elementy zebrane z rozlicznych książek" . Zauważano wprawdzie pewne novum w tworzonych przez niego narracjach, w których pojawiała się psychologiczna analiza postaci, zaledwie zarysowanych w tekstach oryginalnych, ale wiodło to do zarzutów, iż na wzór krytyka literackiego zręcznie tworzy niezwykłe interpretacje prostych w gruncie rzeczy opowieści ${ }^{10}$.

Świadomy źródeł własnych inspiracji Akutagawa wyjaśnia strategię sięgania po motywy i konteksty literatury klasycznej w sposób następujący:

5 Te trzy utwory zyskały Akutagawie uznanie w świecie literatów, stając się przepustką do dalszego tworzenia. Zob. H. Aikawa, Akutagawa Ryūnosuke no "Hankachi"no shiron „„Japanese Literature" 1986, Vol. 35, No. 6, s. 61.

6 T. Hori, Akutagawa Ryūnosuke ron, [w:] Gendai nihon bungaku taikei, t. 43, s. 416.

$7 \mathrm{H}$. Yamanouchi, The Search for Authenticity in Modern Japanese Literature, Cambridge-London-New York-Melbourne 1978, s. 92.

8 S. M. Lippit, Topographies of Japanese Modernism, New York 2002, s. 42.

9 D. Keene, Dawn to the West: Japanese Literature in the Modern Era, New York 1998, s. 565.

10 K. Tsuruta, Akutagawa Ryūnosuke: "The Hell Screen", [w:] Approaches to the Modern Japanese Short Story, eds. T. E. Swann, K. Tsuruta, Tokyo 1982, s. 11. 
Przypuśćmy, że znalazłem temat, który chciałbym rozwinąć w powieści. Żeby nadać mu moc artystyczną, potrzebuję jakiegoś wyjątkowego zdarzenia. Jednak im bardziej wyjątkowe jest to, o czym myślę, tym mniej stosownym miejscem akcji staje się współczesna Japonia. Jeśli osadzę opisywane wydarzenia we współczesności, bez wątpienia nadwyrężę pokładane we mnie zaufanie czytelników. A to z pewnością obróci w niwecz moje szanse na przekazanie im głównego tematu. Mówiąc, że trudno byłoby osadzić niezwykłe wydarzenie w czasach współczesnych, zasugerowałem już jedno z rozwiązań. Otóż należy przenieść wydarzenia do odległych czasów (można w tym celu odwołać się także do przyszłości, choć to rzadkie) lub do kraju innego niż Japonia. Można też zrobić jedno i drugie ${ }^{11}$.

Kontekst literatury klasycznej pozwalał Akutagawie ukazywać ze szczególną mocą to, co stanowiło dla niego zasadniczy temat opowiadania, a równocześnie uniknąć oskarżeń o opisywanie zdarzeń nieprawdopodobnych czy niemożliwych do zaistnienia we wspólczesności. Pisarz uwalniał się tym samym, jak zauważa Lippit, od ważnych dla współczesnej literatury „epistemologicznych pytań o sposób poznawania, ujmowania i przedstawiania rzeczywistości”, a w ten sposób - od rozstrzygania relacji między sztuką a rzeczywistością ${ }^{12}$. Nie konfrontował się z ludzkim doświadczeniem bezpośrednio, ale za pomocą tekstów, które zdołały już wcześniej ująć owo doświadczenie w postaci literackiej fikcji.

Porównanie tekstów, z których Akutagawa czerpał - do jego ulubionych źródeł inspiracji należały zbiory Konjaku monogatari i Uji shūi monogatari - z tym, co sam tworzył, pozwala zauważyć tendencję redukowania elementów nadnaturalnych ${ }^{13}$. Może ona wynikać ze wspomnianej wcześniej przez autora obawy, by nie nadużywać zaufania czytelnika, tej samej obawy, która skłaniała go do osadzania opowiadań w kontekście oddalonym od współczesności w czasie i przestrzeni. Można również zauważyć, że zwłaszcza wczesne utwory pisarza przedstawiają świat autonomiczny, niezależny od jego biografii, co sytuuje je na przeciwległym biegunie utworów naturalistycznych z nurtu „powieści o sobie” $(\text { shishōsetsu })^{14}$.

Źródłem inspiracji Akutagawy we wczesnych utworach są przede wszystkim te opowieści, które występują w literaturze klasycznej wielokrotnie i w różnych ujęciach. W ten sposób pisarz poszukiwał tematów i motywów archetypicznych, które oddawały pewną prawdę o życiu i naturze ludzkiej ${ }^{15}$. Odwołania zaś do archetypów pozwalały nadawać opisywanym przez niego jednostkowym zdarzeniom cechy ponadczasowe i ponadregionalne ${ }^{16}$. Teksty, z których Akutagawa czerpał - zaliczane do setsuwa bungaku (opowieści ludowych), a określane również jako „literatura anegdotyczna” ${ }^{\text {” }}$ - niewątpliwie wywarly również wpływ na sposób narracji w jego opowiadaniach.

Pierwsze opowiadania, w których Akutagawa odwoływał się do istniejących już przekazów, nie skupiając się na wydarzeniach z własnego życia, nie tylko są obrazem jego sprzeciwu względem ograniczania literatury do dosłownego opisu tego, czego on sam doświadczył bezpośrednio, ale dodatkowo podważają postulowany przez naturalistów styl, który

11 M. Ueda, op. cit., s. 116

12 N. Mizuta Lippit, Reality and Fiction in Modern Japanese Literature, White Plains 1980, s. 40.

13 M. Melanowicz, Japońskie narracje. Studia o pisarzach współczesnych, Kraków 2004, s. 70.

14 H. Yamanouchi, op. cit., s. 105.

15 N. Mizuta Lippit, op. cit., s. 42.

16 M. Melanowicz, Japońskie narracje, s. 68.

17 H. Shirane, Setsuwa (anecdotal) literature: Nihon ryōiki to Kokon chomonju, [w:] Cambridge History of Japanese Literature, eds. H. Shirane, T. Suzuki, D. Lurie, Cambridge 2016, s. 286. 
miał być tak neutralny, by nie zwracać na siebie uwagi czytelnika. Stylistyczne założenia naturalistów we wstępie powieści Hatsusugata (Noworoczny strój, 1900) Kosugi Tengai wyłożył następująco:

Nie tworzę, by uczynić zadość własnej fantazji ani by odwoływać się do wyobraźni krytyków czy czytelników. Fantazja jest jak czarka wybornej sake. Ten, kto uwielbia sake, z radością podniesie ją do ust, ale ten, kto jej nie znosi, będzie chciał uciec od stołu z chwilą, gdy tylko poczuje jej zapach. Jestem pewien, że nic w takim stopniu nie zaspokoi pragnienia, zarówno tych, którzy lubią sake, jak i tych, którzy jej nie lubią - jak szklanka zwykłej wody, bez zapachu czy smaku. Chcę, żeby moja twórczość była jak ta zwykła woda. Nie chciałbym, by przypominała sake ${ }^{18}$.

Kosugi w opisie postulowanego przez siebie stylu literackiego posługuje się metaforą wody, która ma podkreślić upragnioną przez naturalistów transparentność języka. Tymczasem język wczesnych opowiadań Akutagawy, będący nie tylko narzędziem opisu, ale także przedmiotem, który można smakować $\mathrm{z}$ rozmysłem i fantazją, należałoby $\mathrm{w}$ tym ujęciu porównać do czarki sake, co pozwala dodatkowo zilustrować tę prawdziwą dla twórczości Akutagawy zależność, iż im większa wiedza czytelnika o stosowanym przez niego stylu, tym głębsza radość czerpana z lektury.

\section{Studium egoizmu w Hana}

Opublikowane w 1916 roku na łamach „Shinshichō” („Nowe Prądy Literackie”) opowiadanie Hana to jeden z pierwszych utworów Akutagawy, który spotkał się z ciepłym przyjęciem w środowisku pisarzy i często jest przeciwstawiany mroczniejszym w wymowie opowiadaniom z tego okresu, takim jak Rashōmon ${ }^{19}$. Szczególnie ważna dla młodego pisarza była opinia cieszącego się wówczas wielkim uznaniem w literackich kręgach Natsumego Sōsekiego, który w liście do Akutagawy napisał:

Sądzę, że utwór ten jest niezmiernie interesujący. Spokojny (ochitsuki ga atte), nie nadmiernie frywolny. Jego wielką zaletą jest to, że pokazuje śmieszność niewymuszoną, w jej naturalnej postaci. Zwraca w nim uwagę również świeżość materiału. Styl jest wprawny i dopracowany. Byłem pod wielkim wrażeniem. Proszę spróbować stworzyć dwadzieścia, trzydzieści podobnych utworów, a stanie się Pan pisarzem, z którym nie będzie mógł się równać nikt z obecnego kręgu literatów $w^{20}$.

Sōseki, który blisko dziesięć lat wcześniej sam zadebiutował utworami o charakterze satyrycznym, jak Wagahai wa neko de aru (Jestem kotem, 1905-1906) i Botchan (Panicz, 1906), zwraca przede wszystkim uwagę na naturalny efekt komiczny w Hana, będący wynikiem sposobu opowiadania. Chwali zwięzłość stylu Akutagawy i jego satyryczne zacięcie ${ }^{21}$. Niezależnie od bezpośredniej inspiracji historią zawartą w Konjaku monogatari (Księga 28,

\footnotetext{
18 D. Keene, Dawn to the West, s. 225.

19 Ibidem, s. 561.

20 H. Yamanouchi, op. cit., s. 90-91.

21 Por. D. Keene, Dawn to the West, s. 562.
} 
rozdział 20: „Opowieść o nosie Zenchi Naigu z Ikenoo”) i w Uji shūi monogatari (Księga 2, rozdział 7: „Rzecz o mnichu, który miał długi nos”), a także możliwych wpływów opowiadania Nos Mikołaja Gogola ${ }^{22}$, mówi o świeżości przedstawianego materiału i wskazuje, że ćwiczenie się w pisaniu w podobnym stylu może sprawić, że Akutagawa stanie się pisarzem niezrównanym, wyjątkowym w gronie ówczesnych twórców (bundan de rui no nai sakka ni naremasu $)^{23}$.

Akutagawa rozpoczyna opowiadanie od przedstawienia sytuacji bohatera z zewnątrz jak dzieje się to także w Konjaku monogatari i Uji shūi monogatari. Stworzony przez niego opis mnicha ma charakter humorystyczny i jest budowany na zasadzie rozwijania kolejnych anegdot, co wskazuje na narracyjne związki tego opowiadania ze wspomnianymi wcześniej przykładami setsuwa bungaku. Akutagawa rozpoczyna od opisu wyglądu bohatera z perspektywy otoczenia: „W całym Ikenoo nie było nikogo, kto by nie słyszał o nosie Zenchi Naigu. Zwisał on z górnej wargi aż pod podbródek, długi na piętnaście czy osiemnaście nawet centymetrów. U nasady tak samo gruby jak u końca, podobny do serdelka, zwisał z samego środka twarzy" ${ }^{24}$. Podobny do serdelka nos, który Konjaku monogatari porównuje do skórki z mandarynki, choć wyśmiewany przez wszystkich wkoło, jest równocześnie znakiem rozpoznawczym mnicha, wyróżniającym go z rzeszy innych postaci - mnichów, okolicznych mieszkańców i wiernych licznie odwiedzających świątynię w Ikenoo.

Dla głównego bohatera zwisający aż po podbródek nos jest powodem rozproszeń podczas nabożeństw. Czas, który powinien spędzać na lekturze sutr, przeznacza on na poszukiwanie sposobu, by prezentować się przed wiernymi w jak najkorzystniejszym świetle, oraz na sprawdzanie w pismach buddyjskich i „,heretyckich”, czy nie było już w historii podobnej mu postaci. Długi nos sprawia, że ludzie kpią także z jego funkcji: „Uważali, że nikt z takim nosem nie znalazłby sobie żony. Byli nawet tacy, którzy złośliwie utrzymywali, że Naigu zo-

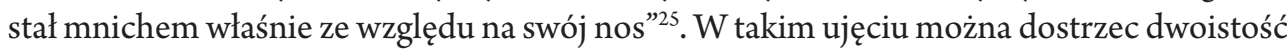
sytuacji Naigu, który jest wysoko postawionym mnichem i z racji swojego zajęcia powinien cieszyć się społecznym uznaniem, a równocześnie - ze względu na swój długi nos - stanowi przedmiot kpin ${ }^{26}$.

Akutagawa nie zatrzymuje się jednak na poziomie zarysu sytuacji mnicha, który stał się obiektem żartów wśród lokalnej społeczności, ale przechodzi do opisu stanu jego uczuć. Naigu, który ma ponad pięćdziesiąt lat, cierpi z powodu nosa w skrytości: „Nawet nie dlatego, że uznawał zamartwianie się własnym nosem za coś, co nie przystoi mnichowi, który winien skupić się wyłącznie na kwestiach przyszłego życia. Przede wszystkim nie chciał, by ludzie wiedzieli, że przejmuje się swoim nosem" 27 .

Obawa Naigu, że stwarzane przez niego pozory niezabiegania o wygląd zostaną w końcu zdemaskowane, jest siłą napędową przedstawianych zdarzeń, chociaż narrator już na

\footnotetext{
22 M. Gogol, Nos, tłum. J. Tuwim, [w:] idem, Wybór pism, Warszawa 1954, s. 199-209. Opowiadanie Gogola miało być pomocne w przejściu od humorystycznego przedstawienia zewnętrznych uwarunkowań bohatera, opisanych w Konjaku monogatari i Uji shūi monogatari, do opisu jego wewnętrznych rozterek. Zob. M. Senda, Akutagawa Ryūnosuke "Hana” ni okeru ikkōsatsu. Kindai bungaku ni arawareta koten no sekai, "Musashino Tanki Daigaku Kenkyū Kiyō" 1989, nr 4, s. 79.

23 H. Yamanouchi, op. cit., s. 90-91.

24 Akutagawa Ryūnosuke, Hana, [w:] Gendai nihon bungaku taikei, t. 43, s. 9.

25 Ibidem, s. 10.

26 H. Yamanouchi, op. cit., s. 90.

27 R. Akutagawa, Hana, s. 9.
} 
wstępie obnaża najglębsze motywacje bohatera, stwierdzając, iż tym, co w istocie cierpiało najbardziej z powodu nosa Naigu, była jego miłość własna. To właśnie ona jest archetypicznym tematem, który Akutagawa rozwija w swojej narracji. Hori Tatsuo zauważa, że zaczerpnięta z Konjaku monogatari opowieść w wydaniu Akutagawy przestaje być jedynie opowiastką humorystyczną, a staje się studium cierpienia Naigu, wynikającego z jego zranionej dumy ${ }^{28}$. Autor pozwala tym samym czytelnikowi na wgląd w tajniki zranionej miłości własnej bohatera.

Przedmiotem pogłębionej refleksji narratora Hana jest jednak nie tylko zachowanie Naigu, ale także postawa tych, którzy się z niego śmieją. Tym bardziej że - co należałoby uznać za paradoks - ów śmiech staje się bardziej szyderczy z chwilą, gdy Naigu udaje się w końcu z pomocą ucznia sprawić, by jego nos uzyskał standardowy rozmiar. Różnica między tym, co główny bohater przewiduje jako konsekwencję zmniejszenia nosa, a rzeczywistym efektem staje się jednym ze źródeł ironii w opowiadaniu.

Mnich nie potrafi zrozumieć, dlaczego nadal - a nawet w większym jeszcze stopniu niż wcześniej - spotyka się z ludzką drwiną. Tym, co mu doskwiera, chociaż nie jest tego w petni świadomy, okazuje się właśnie ów ludzki egoizm, który Naigu wyczuwa podskórnie w zachowaniu obserwatorów w Ikenoo, zarówno mnichów, jak i świeckich ${ }^{29}$. Narrator - który dostrzega znacznie więcej niż Naigu - wplata w opowieść zwięzłą analizę owej postawy drwiącego z mnicha obserwatora:

W sercu człowieka kryją się dwa sprzeczne względem siebie uczucia. Oczywiście każdy współczuje drugiemu w nieszczęściu. Jednak jeśli ów drugi przezwycięży dotychczasowe trudności, wówczas ten, który współczul, zaczyna odczuwać pewne niezadowolenie. Ujmując rzecz nieco przesadnie, można powiedzieć, że rodzi się w nim nawet pragnienie, by ten drugi ponownie zakosztował wcześniejszego nieszczęścia. Nie wiedzieć kiedy w jego sercu pojawia się uczucie wrogości ${ }^{30}$.

Powyższy komentarz stanowi ponurą diagnozę ludzkiej natury i w tej mierze wskazuje na niewidoczną na pierwszy rzut oka bliskość tematyczną opowiadań Hana i Rashōmon, w których głównym przedmiotem zainteresowania narratora (i autora) jest egoizm człowieka. W tym znaczeniu oba opowiadania zapowiadają również kierunek rozwoju twórczości Akutagawy, który uparcie zmierza ku pełniejszemu ukazaniu „piekła ludzkiej samotności” będącego wynikiem zasklepienia w egoizmie ${ }^{31}$. Do jakiego stopnia problem ów zajmował Akutagawę widać w jego liście do przyjaciela z 3 września 1915 roku. „Czy istnieje miłość bez egoizmu?” - pyta w nim. I dodaje: „W egoistycznej miłości nie można przekroczyć dzielących ludzi barier. A w samotności nie można przecież ukoić cierpień dotykających człowieka. Skoro nie ma miłości bez egoizmu, oznacza to, że nie ma nic bardziej bolesnego niż ludzkie życie" ${ }^{32}$. Zawarta w liście do przyjaciela mroczna wizja Akutagawy powraca raz po raz w jego twórczości, znajdując swój najbardziej gorzki wyraz w utworze Aru ahō no isshō (Życie szaleńca, 1927) opublikowanym już po samobójczej śmierci pisarza.

\footnotetext{
28 T. Hori, op. cit., s. 416.

29 H. Yamanouchi, op. cit., s. 90.

30 R. Akutagawa, Hana, s. 12.

M. Senda, op. cit., s. 78.

M. Melanowicz, Japońskie narracje, s. 67.
} 


\section{Imogayu: złudność ludzkich pragnień}

W tym samym roku, w którym opublikowano Hana, ukazało się równieżw uznanym w środowisku literackim czasopiśmie „Shinshōsetsu” („Nowa Powieść”) opowiadanie Imogayu (Kleik $z$ batatów, 1916), w którym Akutagawa podejmuje próbę ponownego opowiedzenia historii znanej z Konjaku monogatari („Toshihito no shōgun wakaki toki Kyō yori Tsuruga ni Goi o ite yukitaru koto”, Księga 26) i z Uji shūi monogatari („Toshihito imogayu no koto”, Księga 1). Opowiadanie Akutagawy spotkało się z różnymi opiniami wśród współczesnych mu pisarzy. Tayama Katai na łamach „Bungakukai” („Świat Literatury”) uznał je za „mało interesujące”33. Także późniejsi twórcy, w tym Dekune Tatsurō, wskazywali, że sposób opowiadania w Imogayu nie jest szczególnie absorbujący, że stworzonym przez Akutagawę postaciom daleko do wyjątkowości, a jego „opisowy styl przypomina miejscami wykład”34. Niezależnie jednak od krytyki, z jaką się spotyka, utwór ten nie przestaje pojawiać się w antologiach literackich i poruszać czytelników także dzisiaj.

Wskazaniu przybliżonego czas akcji w Imogayu - jakim jest koniec ery Gangyō (877-885) bądź początek Ninna (885-889) ${ }^{35}$ - towarzyszy stwierdzenie narratora, że konkretny czas nie odgrywa istotnej roli w opowiadaniu: „Wystarczy, by czytelnik wiedział, że rzecz dzieje się w odległej epoce zwanej Heian"36. Podobny mechanizm można zauważyć w prezentacji postaci: narrator przywołuje Fujiwarę Mototsune (836-891), rzeczywistą postać wpływowego polityka na dworze cesarskim, a równocześnie podkreśla, że wymiar historyczny nie jest kluczowy dla zrozumienia opowieści, zaś czytelnik - zgodnie z zawartym wcześniej wyjaśnieniem założeń twórczych Akutagawy - ma zostać przeniesiony w przeszłość w tym tylko celu, by pełniej mógł wybrzmieć uniwersalny temat poruszany w opowiadaniu. Owo skupienie na wybranym zagadnieniu sprawia, że Imogayu, podobnie jak Hana, bywa zaliczane do opowiadań konceptualnych (jap. tēma shōsetsu) ${ }^{37}$.

Narrator Imogayu od początku zaznacza swoją obecność, dystansując się względem przytaczanej opowieści poprzez komentarze dotyczące sposobu zapisywania historii w przeszłości: „Chciałbym uniknąć pisania »pewien« i podać jego nazwisko, lecz niestety nie zachowało się ono w dawnych kronikach. Pewnie był kimś zwyczajnym, kto nie zasługiwał na odnotowanie. A autorzy dawnych zapisków zasadniczo nie wykazywali zainteresowania zwykłymi ludźmi” ${ }^{38}$. Nieznany z imienia bohater opowiadania Goi (dosłownie „piąta ranga") - identyfikowany dzięki pozycji, jaką zajmował na służbie u Fujiwary Mototsune nabiera cech uniwersalnych, z którymi czytelnik może się zidentyfikowaćc ${ }^{39}$. Jego sytuacja (podobnie jak sytuacja mnicha w Hana) jest naznaczona pewnym paradoksem: to ktoś „niewidoczny jak powietrze” ${ }^{40}$, na kogo otoczenie zwykło nie zwracać uwagi, a równocześnie ktoś, kto stanowi przedmiot nieustających żartów i kpin.

\footnotetext{
33 Ostrze krytyki skierowane było przede wszystkim przeciwko Hankechi, ale zarzutami został objęty również utwór Imogayu. Zob. T. Ishiwari, Taishō gonen no Akutagawa. Dōjidai hyō o chūshin ni, „Komazawa Tandai Kokubun"1978, nr 8, s. 70.

34 T. Dekune, Goi wa nanimonoka, [w:] Sakkatachi ga yonda Akutagawa Ryūnosuke, Tōkyō 2007, s. 54.

35 R. Akutagawa, Imogayu, [w:] Gendai nihon bungaku taikei, t. 43, s. 18.

36 Ibidem.

37 T. Hori, op. cit., s. 417.

38 R. Akutagawa, Imogayu, s. 18.

39 T. Dekune, op. cit., s. 55.

40 R. Akutagawa, Imogayu, s. 19.
} 
Sam narrator również zdaje się chwilami przyjmować ową prześmiewczą perspektywę otoczenia, co widać w pierwszym fragmencie opisującym wygląd bohatera: „Goi miał już ponad czterdzieści lat. Od urodzenia wyróżniał go czerwony nos, jak gdyby przemarznięty, a wąsik miał pro forma, nastroszony, jak gdyby stale hulał w nim wicher z ulicy Sujaku"41. W istocie Goi jest tym, na kogo otoczenie przelewa również własne wady i braki: „kiedy nie umieli przekazać, o co im chodzi, tylko jemu przypisywali niezdolność zrozumienia”ł2. Bohater tymczasem - w przeciwieństwie do mnicha z Ikenoo - zdaje się znosić wszelkie zniewagi i kpiny innych z niewzruszonym spokojem.

$\mathrm{Na}$ tle owego spokoju bohatera jeszcze jaskrawiej rysuje się zapowiedziana już w tytule utworu jego jedyna pasja, będąca tym, co nadaje sens całemu jego istnieniu. Narrator wprowadza temat tego niepohamowanego pragnienia w sposób przemyślany retorycznie, kierując pytanie do czytelnika, na które udziela następnie odpowiedzi: „Czy bohater tej opowieści przyszedł na świat tylko po to, by być poniżanym, bez żadnego pragnienia i celu w życiu? Otóż nie. Od pięciu, sześciu lat Goi żywił niezwykłe pragnienie kleiku z batatów" ${ }^{\prime 3}$. Dla współczesnego czytelnika uznanie kleiku za cel ludzkiego istnienia jawi się jako efekt hiperbolizacji i - co się z tym wiąże - przybiera charakter ironiczny.

Nie miejsce to, by rozstrzygać, w jakim stopniu tytułowy kleik z batatów był w czasach Fujiwary Mototsune potrawą rzadką i pożądaną ${ }^{44}$. Jeśli w istocie w okresie Heian był to rarytas, można uznać, że Konjaku monogatari i Uji shūi monogatari podejmują zagadnienie natury człowieka, który pragnie tego, czego mieć nie może. Akcent pisanego u progu XX wieku Imogayu zostaje tymczasem przeniesiony na niewspółmierność czy też nieadekwatność ludzkiego pragnienia w odniesieniu do jego przedmiotu. Czytelnicy współcześni Akutagawie, mniej zaznajomieni z kontekstem przywołanej w opowiadaniu epoki, dla których imogayu było czymś zwyczajnym i łatwo dostępnym, musieli dostrzegać, że intensywność pragnienia bohatera jest nieadekwatna do przedmiotu, ku któremu było ono kierowane. Ich śmiech można łączyć z reakcją na ogromne pragnienie Goiego, by zdobyć coś, co jest powszechnie dostępne ${ }^{45}$. Takiej ocenie może sprzyjać również przerysowany sposób opisu zachowania bohatera podczas uczty, na której miał okazję kosztować kleiku:

Goi nie mógł myśleć o niczym poza kleikiem. [... ] Siedział z rękami złożonymi na kolanach, czerwieniąc się aż po cebulki oszronionych na skroniach włosów, jak panienka na pierwszym spotkaniu ze swoim przyszłym mężem, i wpatrywał się bez ustanku w stojącą przed nim pustą miseczkę z czarnej laki ${ }^{46}$.

Narrator obserwuje bohatera z nieskrywaną pobłażliwością. Porównuje go do zawstydzonej młodej dziewczyny podczas omiai - pierwszego spotkania z kandydatem na męża. Dostrzega śmieszność jego postawy i zakłada, że czytelnikowi również może się ona jawić jako groteskowa.

41 Ibidem, s. 18-19.

42 Ibidem, s. 19.

43 Ibidem, s. 20.

44 Por. S. Matsuura, Monogatari no juyō. Akutagawa no "saiwa” o megutte, „Hikaku Bungaku Bunka Ronshū” 1986, nr 3, s. 17-30.

45 H. Fujii, Imogayu no kōkogaku to dokusha to iu mondai, „Kokubungaku: kaishaku to kyōzai no kenkyū" 2001, t. 46 , nr 11, s. 50-55.

46 R. Akutagawa, Imogayu, s. 21-22. 
Inną ważną różnicą między tekstem Imogayu a istniejącymi wcześniej opowieściami o Goim jest to, że wcześniejsze przekazy zwykły skupiać się na motywach nadnaturalnych, na przykład lisa na służbie Toshihito, gdy tymczasem w opowiadaniu Akutagawy główny akcent położony jest na finalne zniechęcenie bohatera na widok obfitości imogayu ${ }^{47}$. Okazuje się, że ludzkie wyobrażenia są zawodne, a już sama perspektywa spełnienia marzeń o kleiku $\mathrm{z}$ batatów prowadzi w istocie do rozczarowania. Donald Keene w tym rozczarowaniu dostrzega uniwersalność:

Nie chodziło o stworzenie przekonującego obrazu życia pomniejszego urzędnika w okresie Heian. Goi znany był także we współczesnym społeczeństwie, a rozczarowanie, jakiego doświadcza, pojawia się w dziełach literackich każdego kraju. Bez wątpienia to właśnie uniwersalizm tej opowieści był tak atrakcyjny dla Akutagawy ${ }^{48}$.

W ujęciu Akutagawy znana z tradycji opowieść o pewnym urzędniku na służbie u Fujiwary Mototsune staje się opowieścią o dylemacie człowieka, który jest szczęśliwszy wówczas, gdy jest czegoś pozbawiony i dąży do osiągnięcia upragnionego celu, niż wtedy, gdy jego pragnienie zostaje spełnione ${ }^{49}$. Imogayu ujawnia w ten sposób paradoks ludzkich pragnień, sugerując, że coś, co miało przynieść radość i wyzwolenie od trosk, nie tylko owych wielkich nadziei nie spełniło, ale w istocie żadną miarą spełnić ich nie mogło.

Warto nadmienić jeszcze, że Akutagawa czerpał nie tylko z Konjaku monogatari czy Uji shūi monogatari, ale także z literatury obcej, co pozwalało mu spojrzeć na przedstawianą historię z nowej perspektywy. Opis Goiego, zwłaszcza w pierwszej części opowiadania, inspirowany jest obficie opowiadaniem Gogola Szynel (Шинель, 1842) ${ }^{50}$. W Imogayu, tak jak w Szynelu, podkreślono, że szczegółowy opis czasu i przestrzeni nie jest ważnym czynnikiem w narracji.

W opowiadaniu Gogola rzecz dzieje się w „pewnym departamencie”, w którym służył „pewien urzędnik”. Stworzony przez Gogola Akakiusz Kamaszkin (ros. Baszmaczkin - pochodzi od słowa „trzewik”), podobnie jak Goi, opisywany jest głównie przez odniesienie do pełnionej funkcji radcy tytularnego. Choć pozornie niczym się nie wyróżnia, stanowi przedmiot żartów swojego otoczenia, a opis tego, jak jest traktowany, mógł być bezpośrednią inspiracją dla Akutagawy:

Młodzi urzędnicy wyśmiewali się z niego i podżartowywali, ile im starczyło dowcipu kancelaryjnego; opowiadali wobec niego najrozmaitsze, wymyślone o nim historie; o jego gospodyni, siedemdziesięcioletniej babinie, mówili, że go bije; pytali, kiedy się odbędzie ich wesele; sypali mu na głowę papierki, nazywając to śniegiem. Ale pan Akakiusz nie odpowiadał na to ani słówkiem, jak gdyby w ogóle nikogo przy nim nie było ${ }^{51}$.

Postawa Akakiusza, podobnie jak Goiego, jest skontrastowana z zachowaniem otoczenia, które bywa okrutne i bezrefleksyjne w swoich osądach i działaniach. Bohaterowie Gogola i Akutagawy - choć sami uosabiają cechy natury ludzkiej poddawane krytycznej

\footnotetext{
47 T. Hori, op. cit., s. 417.

48 D. Keene, Dawn to the West, s. 564-565.

49 Por. H. Yamanouchi, op. cit., s. 91.

50 M. Gogol, Szynel, tłum. J. Wyszomirski, [w:] idem, Wybór pism, Warszawa 1954, s. 233-246.

51 Ibidem, s. 234.
} 
ocenie - są równocześnie soczewką, w której skupia się egoizm innych ludzi. „Przestańcie. Czemu mnie krzywdzicie?"52 - pytają. Motywowani jednym pragnieniem (Akakiusz płaszcza, Goi kleiku z batatów) wywołują zdecydowane reakcje otoczenia, także czytelników, którzy niejednokrotnie dołączają do grona szyderców. Akutagawa jednak ostrze ironii kieruje także w stronę kpiących widzów. „Człowiek czasami poświęca życie pragnieniu, o którym nie wie, czy się ziści. Ci, którzy śmieją się z takiej głupoty, są zaledwie obserwatorami życia"53 - zauważa, skłaniając czytelnika do refleksji nad własną postawą.

\section{Ograniczający manieryzm w Hankachi}

Opowiadanie Hankachi (Chusteczka) ze względu na osadzenie fabuły we współczesności może wydawać się zasadniczo różne od dwóch utworów analizowanych wcześniej ${ }^{54}$. Uznane przez Mishimę Yukio za najbardziej dopracowany utwór Akutagawy ${ }^{55}$, ukazało się w prestiżowym czasopiśmie „Chūō Kōron” („Ośrodek Publicznej Debaty”) i, w duchu polemiki, odwoływało się do znanej powszechnie i cenionej postaci Nitobe Inazō - nauczyciela i doradcy rządowego w kwestiach kolonialnych, dyrektora Daiichi Kōtō Gakkō w czasie, kiedy do szkoły tej uczęszczał Akutagawa, i autora słynnej publikacji Bushidō the Soul of Japan $(1900)^{56}$. Akutagawa w wykładzie Asu no dōtoku (Moralność jutra) wygłoszonym w Tokio w 1914 roku nawiązał do postaci Nitobe Inazō, podkreślając, że głoszony przez dyrektora Daiichi Kōtō Gakkō pogląd, jakoby człowiek w żadnym razie nie powinien przyznawać się przed innymi do swoich słabości, był dla niego w czasach szkolnych nie do przyjęcia ${ }^{57}$.

Hankachi to pierwszy utwór Akutagawy, którego bohater jest w jakiejś mierze wzorowany na postaci rzeczywistej ${ }^{58}$. Związek bohatera - profesora Hasegawy Kinzō z uznanym w czasach Akutagawy pedagogiem musiał przykuwać uwagę czytelników, o czym sam autor pisał z obawą w liście do Toyokichiego Haty z 25 września 1916 roku: „Dla »Chūōkōron« nakreśliłem sylwetkę pana Nitobe Inazō i modlę się teraz, by reakcje społeczeństwa nie były dla mnie nieprzyjemne" ${ }^{59}$. W tym samym liście Akutagawa określił swój utwór jako gurūdo (od angielskiego glued) - „posklejany” ${ }^{\prime}$. Kilka lat później z kolei wspominał, że Takida Chokin, redaktor „Chūō Kōron”, zwrócił uwagę na zawartą w Hankachi ironię ${ }^{61}$. Idąc wyznaczonym przez redaktora tropem, późniejsi krytycy również zwykli skupiać się na ironicznej

52 Ibidem.

53 R. Akutagawa, Imogayu, s. 20.

54 Por. H. Aikawa, op. cit., s. 61.

55 Keene polemizuje z takim poglądem, wskazując na Jigokuhen (Piekieł wizerunek niezwykły, 1918) jako tekstmisterniej zaplanowany. Por. D. Keene, Kindai bungaku o yomu, Tōkyō 1977, s. 131.

56 I. Nitobe, Bushido. The Soul of Japan. An Exposition of Japanese Thought, Philadelphia 1900. Tekst ukazał się najpierw w języku angielskim; w 1908 roku pojawiło się tłumaczenie na japoński.

57 R. Akutagawa, Asu no dōtoku, [w:] Akutagawa Ryūnosuke zenshū, t. 12, Tōkyō 1996, s. 10-11. Por. H. Kanda, Akutagawa "Hankachi" ron. Teikoku shugi teki gensetsu no naka de „Aoyama Gorun” 2004, nr 34, s. 127.

58 W Gesaku zanmai (Pasja twórcza, 1917) Akutagawa stworzył fikcyjny obraz pisarza okresu Edo Takizawy Bakina. W późniejszych utworach odwoływał się bardziej do własnych doświadczeń, tworząc postaci (na przykład w Aru ahō no isshō) będące w jakiejś mierze jego porte-paroles.

59 N. Aikawa, Akutagawa Ryūnosuke "Hankachi"ron. Nitobe Inazō no eikyō, „Kindai bungaku shiron” 2002, nr 40, S. 35.

60 H. Aikawa, op.cit., s. 61.

61 H. Kanda, op. cit., s. 118. 
wymowie utworu Akutagawy, widząc w osobie profesora Hasegawy karykaturę kosmopolity okresu Taishō, a w jego rozważaniach nieudolne próby ujmowania rzeczywistości w kategoriach łączących w sposób wyidealizowany wartości chrześcijańskie z kodeksem bushidō ${ }^{62}$.

Kontekstem dla zrozumienia ironii w Hankachi jest zatem nie tylko sama postać Nitobe Inazō, ale także jego dzieło: Bushidō. The Soul of Japan, wydane pierwotnie z myślą o odbiorcy spoza Japonii i stanowiące próbę przedstawienia japońskiego systemu wartości etycznych w taki sposób, by można go było zestawić z chrześcijaństwem oraz z europejskim ideałem rycerskości. W napisanej w 1899 roku przedmowie do angielskiego wydania Nitobe Inazō wskazuje, że punktem wyjściowym jego rozważań nad japońskim systemem moralnym było pytanie o wychowanie religijne bądź etyczne w szkole, jakie postawil mu znajomy prawnik z Belgii, a jednym z celów - wyjaśnienie żonie, Amerykance Mary Patterson, w jaki sposób określone wartości przetrwały w Japonii ${ }^{63}$.

Nitobe wymienia kilka cech, które charakteryzują japońskiego wojownika, a do których należą kolejno opisywane: prawość i sprawiedliwość, odwaga i męstwo, szlachetność i współodczuwanie ze światem, grzeczność, prawdziwość, honor, lojalność, wykształcenie i panowanie nad sobą. W kontekście Hankachi Akutagawy szczególnie istotne wydają się rozdziały o grzeczności i prawdziwości. „Grzeczność - pisze Nitobe - jest marną cnotą, jeśli wynika jedynie z lęku, by nie uchybić dobremu smakowi, powinna być raczej zewnętrznym wyrazem współczucia wobec innych" ${ }^{\prime 4}$. Jeśli jest pozbawiona prawdziwości i szczerości, „jest farsą” - dodaje ${ }^{65}$. Akutagawa w swoim opowiadaniu tworzy wspomnianą w Bushidō sytuację farsy, ukazując z ironicznym dystansem sztuczność przekonań profesora Hasegawy.

Dystans narratora Hankachi wobec poglądów głównego bohatera można również wpisać w szerszy kontekst społecznej krytyki względem umacniającego się po wojnie japońsko-rosyjskiej nurtu budowania nowoczesnej japońskiej tożsamości i propagowania japońskości na arenie międzynarodowej ${ }^{66}$. W tym ujęciu Hakachi może stanowić zapowiedź późniejszych utworów Akutagawy, krytycznych względem oficjalnego stanowiska rządu japońskiego i wytyczonych przez niego politycznych celów, między innymi powstałego siedem lat później opowiadania Shōgun (Generat, 1922) oraz słynnej antyutopii Kappa (1927).

Postać profesora Hasegawy Kinzō, na której skupia się uwaga narratora - zgodnie z obawą Akutagawy - spotkała się z pewną krytyką w chwili publikacji opowiadania. Zarzucano jej, że jest pozbawiona wyrazistego charakteru, a jej zachowanie w stosunku do matki zmarłego ucznia wydaje się zgoła niezrozumiałe ${ }^{67}$. Niewątpliwą trudność w odbiorze profesora rodziła wielopoziomowa ironia, z jaką odnosi się do niego narrator, który stara się kierować odczuciami czytelnika i uprzedzać jego reakcję. Czytający Dramaturgię Strindberga Hasegawa - specjalista od polityki kolonialnej - może rodzić zdumienie odbiorcy, które narrator przewiduje, tłumacząc: „Jak przystało jednak na profesora, który cieszył się uznaniem nie tylko jako badacz, ale także jako pedagog, zwykł on sięgać, jeśli czas mu na to pozwalał, po te książki - także spoza obszaru swoich badań - które miały związek z myśleniem

\footnotetext{
62 Por. S. Yoshida, Akutagawa Ryūnosuke, Tōkyō 1942, s. 12.

63 I. Nitobe, op. cit., s. v.

64 Ibidem, s. 28.

65 Ibidem, s. 37

66 H. Kanda, op. cit., s. 124.

67 H. Aikawa, op. cit., s. 62.
} 
i odczuwaniem współczesnych studentów"68. Wyjaśnienie narratora służy jednak podaniu w wątpliwość rzeczywistego zainteresowania profesora, którego postawa przypomina „typowego nauczyciela języka angielskiego w gimnazjum", sięgającego do filozofii i literatury „w poszukiwaniu idiomów”

Sposób, w jaki Hasegawa Kinzō czyta książki, wydaje się zbieżny z jego ogólnym podejściem do cywilizacji i kultur, które postrzega schematycznie przez pryzmat występujących w nich osobliwości. Ilustracją takiej postawy jest przywołane wspomnienie z czasu jego studiów w Prusach, kiedy nie potrafił zrozumieć płaczu dzieci po śmierci króla Wilhelma I Hohenzollerna. Konkretna scena rodzi jego nieufność, prowadząc go do ogólniejszych wniosków na temat cywilizacji zachodniej, cechującej się „żywiołowym wyrazem uczuć”70. W sposób analogiczny profesor odczytuje brak widocznych emocji w kobiecie, która przyszła powiedzieć mu o śmierci syna - jednego z jego uczniów. Widok gniecionej pod stolikiem chusteczki w dłoniach kobiety skłania Hasegawę do ogólniejszej refleksji na temat różnic między Zachodem i Wschodem. Nishiyama Atsuko, matka zmarłego młodzieńca, staje się dla niego uosobieniem japońskich wartości bushidō. Tym samym profesor jest ukazany jako obserwator, „osoba z zewnątrz”, ktoś, kto patrzy z dystansu zarówno na kulturę zachodnią, jak i na zwyczaje rodzime ${ }^{71}$.

Dążenie Hasegawy Kinzō do schematycznego ujmowania rzeczywistości - widoczne w jego podejściu do lektury, cywilizacji i ludzi - zostaje ujęte w ramy dwóch cytatów zaczerpniętych z Dramaturgii Strindberga. Przed niespodziewaną wizytą matki swojego ucznia profesor czyta passus poświęcony schematycznej grze aktora:

Kiedy aktor znajdzie jakąś odpowiednią formę wyrazu dla najzwyczajniejszych uczuć i dzięki temu odniesie tryumf, wówczas skłonny jest stosować ową formę niezależnie od tego, czy jest odpowiednia, czy też nie, po części dlatego, że jest wygodna, a po części dlatego, że przyniosła mu sukces. To właśnie można określić mianem maniery ${ }^{72}$.

Cytat ten staje się kontekstem, w którym można odczytywać kolejne gesty profesora Hasegawy. Jego sposób przyjęcia Nishiyamy Atsuko nosi znamiona teatralności - każdy ruch jest zaplanowany i przemyślany ze względu na efekt, jaki może wywołać. Obserwacja kobiety wiodąca profesora do uznania jej za uosobienie wartości bushidō daje mu uczucie zadowolenia wynikającego $\mathrm{z}$ odnalezienia właściwego klucza interpretacji nie tylko tego jednostkowego spotkania, ale również całej współczesnej mu kultury Japonii.

Jego zadowolenie zostaje jednak zmącone w wyniku lektury dalszych słów Strindberga, na które wzrok profesora pada już po odejściu kobiety:

68 R. Akutagawa, Chusteczka, tłum. K. Sonnenberg, [w:] Sny i wizje w japońskich opowiadaniach przełomu XIX iXX wieku, red. K. Sonnenberg, Kraków 2017, s. 169.

69 Ibidem, s. 171.

70 Ibidem, s. 174.

71 T. Weingärtner, Samurai Smiles? Unique Guiles? Reflections on Japanese Smiles, Laughter and Humour, [w:] Eastwards. Western Views on East Asian Culture, ed. F. Kraushaar, Bern 2010, s. 237.

72 R. Akutagawa, Chusteczka, s. 170. 
Kiedy byłem młody, słyszałem opowieść o chusteczce i niejakiej pani Heiberg, maniera ta powstała najpewniej w Paryżu. Chodziło o podwójną grę, kiedy z uśmiechem na twarzy rozdzierała na dwoje chustkę. Określamy to teraz mianem trików (Mätzchen $)^{73}$.

Strindberg odwołuje się do gry Johanne Luise Heiberg, która występowała na deskach duńskiego teatru ${ }^{74}$. Domyślamy się, że ów krytyczny komentarz profesor Hasegawa odnosi do Nishiyamy Atsuko, która $\mathrm{z}$ łagodnym uśmiechem na twarzy mówiła o śmierci syna, szarpiąc pod stołem chusteczkę. Dla czytelnika jednak przykładem „triku” czy „maniery”, o której pisze Strindberg, jest przede wszystkim zachowanie samego profesora, posługującego się stale jednym tylko schematem w pojmowaniu świata, po części dlatego, że jest on wygodny, a po części dlatego, że przyniósł mu już uznanie społeczne. Ów rozdźwięk między spojrzeniem Hasegawy i perspektywą czytelnika jest jednym ze źródeł ironii w opowiadaniu, które samo w sobie stanowi również świadectwo wyrafinowanego manieryzmu, i jako takie jest przykładem zastosowania meta-ironii ${ }^{75}$.

\section{Zakończenie}

Hana, Imogayu i Hankachi - opowiadania, którymi w 1916 roku Akutagawa zapewnił sobie miejsce wśród najzdolniejszych pisarzy okresu Taishō - chociaż często przeciwstawiane jego późniejszym, bardziej autobiograficznym utworom, zapowiadają tematy i techniki, które pisarz rozwijał do końca swojego życia. W utworach tych powraca problem ludzkiego egoizmu i łatwości oceny innych. Bohaterowie nie są zdolni rozpoznać własnych najgłębszych pragnień i lęków. Mnich z Ikenoo cierpi nie tyle z powodu swojego nosa, co ze względu na zranioną miłość własną. Goi nie przypuszcza nawet, że sama wizja zaspokojenia pragnienia kleiku z batatów odbierze mu radość życia. Profesor Hasegawa Kinzō - choć przekonany o nieomylności własnych sądów - zatrzymuje się w swojej ocenie jedynie na powierzchni zjawisk.

Odwołania do już istniejących konkretnych opowieści, niosących w sobie ładunek archetypiczny, czy do postaci Nitobe Inazō, która uosabiała ideały epoki Meiji, pozwalają przenieść rozważania na poziom bardziej ogólnych stwierdzeń o naturze człowieka. Owa refleksja uniwersalna ważna jest także w późniejszych utworach Akutagawy i często przyjmuje formę przypowiastek filozoficznych bądź aforyzmów ${ }^{76}$.

Jedną z podstawowych strategii opisu kondycji ludzkiej stosowanych przez Akutagawę jest ironia wynikająca z różnicy w tym, jak daną sytuację postrzegają bohater, narrator oraz czytelnik, do którego adresowane są filozoficzne w swej istocie pytania o granice poznania i zakres ludzkiego egoizmu. Śmiech będący wynikiem obserwacji egoistycznych zachowań bohaterów ostatecznie zwraca się również przeciwko czytelnikowi, który przyjmując rolę „obserwatora życia”77, upodabnia się do rzeszy szyderców z Hana i Imogayu oraz Hasegawy

\footnotetext{
73 Ibidem, s. 176.

74 A. H. Thomas, Historical Dictionary of Denmark, London 2016, s. 254.

75 K. Hirano, Hankachi, [w:] Sakkatachi ga yonda Akutagawa Ryūnosuke, Tōkyō 2007, s. 73.

76 M. Melanowicz, Historia literatury japońskiej, Warszawa 2011, s. 360.

77 R. Akutagawa, Imogayu, s. 20.
} 
Kinzō z Hankachi. Równolegle do pytania o naturę człowieka pojawia się w tych wczesnych utworach również pytanie o znaczenie pisania ${ }^{78}$. To samo, które zaowocuje refleksją teoretycznoliteracką w późniejszych latach życia Akutagawy. Oddalając się stopniowo od źródeł, które go inspirują, pisarz zwraca uwagę czytelnika na strukturę i możliwości opowieści, a ironia pozwala mu zachować dystans do stosowanej formy i unikać pułapek manieryzmu w tworzeniu.

\section{Bibliografia}

Aikawa Hirofumi, Akutagawa Ryūnosuke no "Hankachi" no shiron, "Japanese Literature” 1986, Vol. 35, No. 6.

Aikawa Naoyuki, Akutagawa Ryūnosuke „Hankachi”ron. Nitobe Inazō no eikyō, „Kindai bungaku shiron" 2002, nr 40.

Akutagawa Ryūnosuke, Bungeitekina, amari bungeitekina, [w:] Gendai nihon bungaku taikei, t. 43: Akutagawa Ryūnosuke shū, Tōkyō: Chikuma shobō, 1977.

—, Hana, [w:] Gendai nihon bungaku taikei, t. 43: Akutagawa Ryūnosuke shū, Tōkyō: Chikuma shobō, 1977.

—, Imogayu, [w:] Gendai nihon bungaku taikei, t. 43: Akutagawa Ryūnosuke shū, Tōkyō: Chikuma shobō, 1977.

—, Asu no dōtoku, [w:] Akutagawa Ryūnosuke zenshū, t. 12, Tōkyō: Iwanami shoten, 1996.

-, Chusteczka, thum. Katarzyna Sonnenberg, [w: Sny i wizje w japonskich opowiadaniach przetomu XIX i XX wieku, red. Katarzyna Sonnenberg, Kraków: Wydawnictwo Uniwersytetu Jagiellońskiego, 2017.

Dekune Tatsurō, Goi wa nanimonoka, [w:] Sakkatachi ga yonda Akutagawa Ryūnosuke, Tōkyō: Takarajimasha, 2007.

Fujii Hidetada, Imogayu no kōkogaku to dokusha to iu mondai, „Kokubungaku: kaishaku to kyōzai no kenkyū" 2001, t. 46, nr 11.

Gogol Mikołaj, Nos, tłum. Julian Tuwim, [w: ] Mikołaj Gogol, Wybór pism, Warszawa: Książka i Wiedza, 1954.

—, Szynel, tłum. Jerzy Wyszomirski, [w: ] Mikołaj Gogol, Wybór pism, Warszawa: Książka i Wiedza, 1954.

Hashiura Hiroshi, Yokomitsu Riichi - kankaku to shukumei, „Kokubungaku: kaishaku to kyōzai no kenkyū" 2001, t. 46, nr 11.

Hirano Keiichirō, Hankachi, [w:] Sakkatachi ga yonda Akutagawa Ryūnosuke, Tōkyō: Takarajimasha, 2007.

Hori Tatsuo, Akutagawa Ryūnosuke ron, [w:] Gendai nihon bungaku taikei, t. 43: Akutagawa Ryūnosuke shū, Tōkyō: Chikuma shobō, 1977.

Ishiwari Tōru, Taishō gonen no Akutagawa. Dōjidai hyō o chūshin ni, „Komazawa Tandai Kokubun” 1978 , nr 8.

Kanda Hidemi, Akutagawa „Hankachi” ron. Teikoku shugi teki gensetsu no naka de, „Aoyama Gorun” 2004, nr 34.

Keene Donald, Kindai bungaku o yomu, Tōkyō: Shinchōsha, 1977.

-, Dawn to the West: Japanese Literature in the Modern Era, New York: Columbia University Press, 1998.

\footnotetext{
78 H. Hashiura, op. cit., s. 36.
} 
Lippit Seiji M., Topographies of Japanese Modernism, New York: Columbia University Press, 2002.

Matsuura Shunsuke, Monogatari no juyō. Akutagawa no „saiwa” o megutte, „Hikaku Bungaku Bunka Ronshū" 1986, nr 3.

Melanowicz Mikołaj, Japońskie narracje. Studia o pisarzach wspótczesnych, Kraków: Wydawnictwo Uniwersytetu Jagiellońskiego, 2004.

—, Historia literatury japońskiej, Warszawa: Wydawnictwo Naukowe PWN, 2011.

Mizuta Lippit Noriko, Reality and Fiction in Modern Japanese Literature, White Plains, NY: M. E. Sharpe, 1980.

Nitobe Inazo, Bushidō. The Soul of Japan. An Exposition of Japanese Thought, Philadelphia, PA: The Leeds \& Biddle Co., 1900.

Senda Minoru, Akutagawa Ryūnosuke „Hana” ni keru ikkōsatsu. Kindai bungaku ni arawareta koten no sekai, „Musashino Tanki Daigaku Kenkyū Kiyō” 1989, nr 4.

Shirane Haruo, Setsuwa (anecdotal) literature: Nihon ryōiki to Kokon chomonju, [w:] Cambridge History of Japanese Literature, eds. Haruo Shirane, Tomi Suzuki, David Lurie, Cambridge: Cambridge University Press, 2016.

Thomas Alastair H., Historical Dictionary of Denmark, London: Rowman \& Littlefield, 2016.

Tsuruta Kin'ya, Akutagawa Ryūnosuke: "The Hell Screen", [w:] Approaches to the Modern Japanese Short Story, eds. Thomas E. Swann, Kin'ya Tsuruta, Tokyo: Waseda University Press, 1982.

Ueda Makoto, Modern Japanese Writers, Stanford, CA: Stanford University Press, 1976.

Washburn Dennis C., The Dilemma of the Modern in Japanese Fiction, New Haven, CT-London: Yale University Press, 1995.

Weingärtner Till, Samurai Smiles? Unique Guiles? Reflections on Japanese Smiles, Laughter and Humour, [w: Eastwards. Western Views on East Asian Culture, ed. Frank Kraushaar, Bern: Peter Lang, 2010.

Yamanouchi Hisaaki, The Search for Authenticity in Modern Japanese Literature, Cambridge-London-New York-Melbourne: Cambridge University Press, 1978.

Yoshida Sei’ichi, Akutagawa Ryūnosuke, Tōkyō: Sanseidō, 1942. 